\title{
ASSESSING THE IMPACTS OF CLIMATE CHANGE ON THE HYDROLOGY OF THE INDRAWATI RIVER BASIN, NEPAL
}

\author{
B. Bade ${ }^{1, *}$, D. R. Gyawali ${ }^{2}$, S. Timilsina ${ }^{3}$ \\ ${ }^{1}$ GIS Developer, International Maize and Wheat Improvement Center (CIMMYT), Lalitpur, Nepal - bikesbade@gmail.com \\ ${ }^{2}$ Data Analyst (Spatial Modeling), United Nations World Food Programme (UNWFP), Kathmandu, Nepal - dheeraz@gmail.com \\ ${ }^{3}$ GIS Analyst, Nepal Development Research Institute (NDRI), Lalitpur, Nepal - shirisa123@gmail.com
}

\section{Commission V, WG V/7 \& Commission IV, WG IV/6}

KEY WORDS: Climate change, Arc SWAT, Indrawati River, Hydrological Modelling

\begin{abstract}
:
This study details climate change assessment of the hydrological regime of Indrawati basin of Nepal. The study uses Soil and Water Assessment Tool (SWAT) model to delineate, discretize and parameterize the Indrawati basin to compute model's input parameters. The model was then run for 1990-2014 to simulate the discharge at the outlet (Dholalghat). The coefficient of determination $R^{2}$ and NashSutcliffe (ENS) were used to evaluate model calibration and validation. The results found were satisfactory for the gauging station $R^{2}=$ 0.951 and ENS $=0.901$ for calibration and $R^{2}=0.937$ and. ENS $=0.906$ for validation. The calibrated hydrological model was run for the future climate change scenario using the RegCM4-LMDZ4 data and the relative changes with the baseline scenarios were analyzed. The comparison suggests that the historical trend of flow is decreasing at the rate of $0.55 \mathrm{~m}^{3} / \mathrm{s}$ per year. According to RegCM4-LMDZ4 simulations, the trend is going to continue but at a flatter rate. The decreasing trend is observed to be very less. The characteristic peak flow month in the historical scenario is August but the RegCM4-LMDZ4 led simulated flows suggest a shift in monthly peak to October suggesting decrease in monsoon flows and a subsequent significant increase in flows from October to January.
\end{abstract}

\section{INTRODUCTION}

Nepal is largely a mountainous country. The climate in Nepal varies from the tropical to the arctic within the $200 \mathrm{~km}$ span from south to north. National mean temperatures hover around $15^{\circ} \mathrm{C}$ and increase from north to south except for mountain valleys. Average rainfall is $1,500 \mathrm{~mm}$, with rainfall increasing from west to east. Rainfall also varies by altitude; areas over $3,000 \mathrm{~m}$ experience a lot of drizzle while heavy downpours are common below 2,000 m (Team-Nepal, 1997). Climate in the Indrawati basin is primarily governed by the interaction of the South Asian monsoon system and the Himalayas. Heavy rainfall, relatively high temperatures, and humidity characterize the summer months from roughly mid-May to mid-October; nearly half the total annual rainfall occurs in the months of July and August. Temperatures range from 5 degrees to 32.5 degrees Centigrade (Sharma C. , 2002). In the present condition, Indrawati has poor land use practices, improper management systems and lack of appropriate soil conservation measures, which lead water resources to degrade with the time. With issue of climate change which is being highly raised and while on the other hand Melamchi water supply project development is questionable as the flow in perennial rivers is under change with significantly reduced dry season flow, this is likely to cause serious problems in the design of different water infrastructures in the Indrawati basin. The specific objectives of this research is to run the ArcSWAT model on Indrawati River Basin and to assess the impact of climate change on the hydrology of the Indrawati basin.
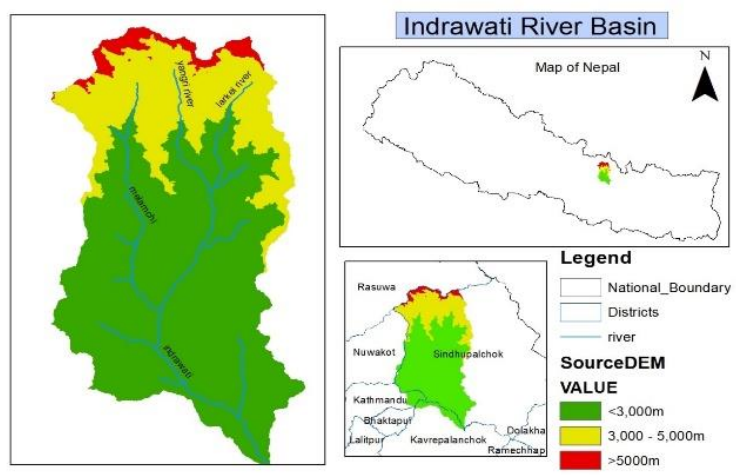

Figure 1. Indrawati River Basin (Study Area)

\section{STUDY AREA}

The Indrawati river basin is located in the central Nepal, approximately $50 \mathrm{~km}$ north east from the capital city of Nepal in Kathmandu (Fig. 1) and is the part of the larger Koshi basin. The Indrawati River originates in the high Nepali Himalayas, eventually joining the Sun Koshi. The Indrawati river basin is an important river basin due to its significance in water diversion into the Kathmandu Valley.

The river basin is situated in the mid-hills of Nepal and has a high variation in altitude. The altitude ranges from 595 to 5838 $\mathrm{m}$ above sea level (msl). Both snowmelts and spring sources

\footnotetext{
* Corresponding Author
} 
contribute to the base flow of the river. The basin lies within the latitude $27^{\circ} 27^{\prime} 11^{\prime \prime} \mathrm{N}-28^{\circ} 10^{\prime} 12^{\prime \prime} \mathrm{N}$ and longitude $85^{\circ} 45^{\prime} 21^{\prime \prime} \mathrm{E}-$ $85^{\circ} 260^{\prime} 6^{\prime \prime}$ E with a total drainage area of $1230 \mathrm{~km} 2$. The main tributaries of the Indrawati River are Melamchi, Yangri, Larke, Mahadev, Chaa, Handi, and Jhyangri. Among all the tributaries, water from the Melamchi, Yangri, and Larke Rivers is planned for diversion into the Kathmandu Valley (Bhattarai, 2002).

\section{DATA AND RESEARCH METHODOLOGY}

The overall methodology of the study is represented in the diagram below. Methodology is based on the Arc Swat hydrological modeling workflow. Data required for the modeling is collected and fitted on the model on after another and done the analysis as show in the diagram

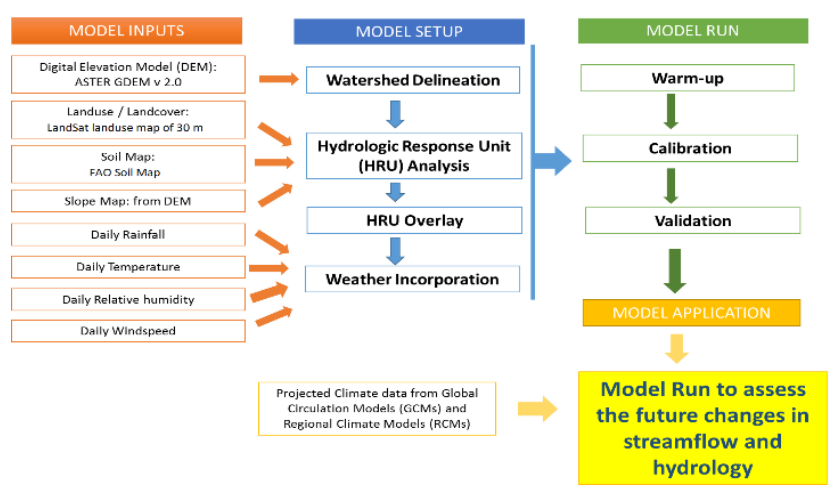

Figure 2. Flow diagram of the study

For this, following spatial and spatial-temporal data were acquired, prepared and used as inputs, and the processes were implemented to meet the objectives of the study.

\subsection{Topographical Data}

The topography of the Indrawati watershed basin was defined by the ASTER GDEM v2.0. It has spatial resolution of $30 \mathrm{~m}$. A DEM represents the 3-dimensional topographic features of the study area. The DEM used in this study is of $30 \mathrm{~m} \times 30 \mathrm{~m}$ grid size. Sub basin parameters such as slope gradient, slope length of the terrain and the stream network characteristics such as slope length and width were derived from DEM.

\subsection{Land Use}

The Landsat derived land use map with a spatial resolution of $30 \mathrm{~m}$ obtained from International Centre for Integrated Mountain Development (ICIMOD)'s geo-portal was used for the study. The reclassification of the land use map was done to represent the land use according to the specific land use / cover types and the respective parameters defined in the SWAT database. Land use map is reclassified to represent the respective parameters were selected from SWAT database. A look up table that identifies the 4-letter SWAT code for the different categories of land cover/land use was prepared to relate the grid values to
SWAT land cover/land use classes. SWAT calculated the area covered by each land use.

\subsection{Soil Data}

The SWAT model requires different soil textural and physicalchemical properties such as soil texture. These data were obtained mainly from the FAO soil properties database (FAO, 2002) and other sources. A FAO Soil map was downloaded and clipped for the Indrawati river Basin using ArcGIS spatial analyst tools.

\begin{tabular}{|l|l|l|l|l|}
\hline $\begin{array}{l}\text { Station } \\
\text { Name }\end{array}$ & ID & $\begin{array}{l}\text { Latitude } \\
\text { (degree) }\end{array}$ & $\begin{array}{l}\text { Longitude } \\
\text { (degree) }\end{array}$ & $\begin{array}{l}\text { Elevation } \\
\text { (meter) }\end{array}$ \\
\hline NAWALPUR & 1008 & 27.80 & 85.61 & 1592.00 \\
\hline DUBACHAUR & 1017 & 27.86 & 85.56 & 1550.00 \\
\hline BAUNEPATI & 1018 & 27.78 & 85.56 & 845.00 \\
\hline MANDAN & 1020 & 27.70 & 85.65 & 1365.00 \\
\hline DOLAL GHAT & 1023 & 27.63 & 85.71 & 710.00 \\
\hline DHAP & 1025 & 27.91 & 85.63 & 1240.00 \\
\hline SANKHU & 1035 & 27.75 & 85.48 & 1449.00 \\
\hline NAGARKOT & 1043 & 27.70 & 85.51 & 2163.00 \\
\hline $\begin{array}{l}\text { TARKE } \\
\text { GHYANG }\end{array}$ & 1058 & 28.00 & 85.55 & 2480.00 \\
\hline
\end{tabular}

Table 1. Meterological station in project site

\subsection{Meteorological Data}

Meteorological data is needed by the SWAT model to simulate the hydrological conditions of the basin. The meteorological data required for this study were collected from the Department of Hydrology and Meteorology (DHM) of Nepal. The meteorological data collected were daily precipitation, daily maximum and minimum temperature. Data from 8 stations, which are within and around the study area, were collected.

\subsection{Hydrological data}

The hydrological data was required for two purposes, first for performing sensitivity analysis, calibration and validation of the model, and the latter one was to define inlet discharge points for the basin. The hydrological data for both purposes were collected from the hydrology section of the DHM.

\begin{tabular}{|l|l|l|l|l|}
\hline $\begin{array}{l}\text { Station } \\
\text { ID }\end{array}$ & River & Site Name & $\begin{array}{l}\text { Latitude } \\
\text { (degree) }\end{array}$ & $\begin{array}{l}\text { Longitude } \\
\text { (degree) }\end{array}$ \\
\hline 629 & $\begin{array}{l}\text { Indrawati } \\
\text { River }\end{array}$ & Dolalghat & 27.64 & 85.71 \\
\hline
\end{tabular}

Table 2. Hydrological Station in project site 


\section{SWAT MODEL SETUP}

Geographic information systems data for the SWAT model were preprocessed by two separate functions watershed delineation and determination of hydrologic response units (HRUs) and outlined in the next subtopics in detail:

\subsection{Watershed delineation}

Arc SWAT uses Digital Elevation Model (DEM) data to automatically delineate the watershed into several hydrologically connected sub-watersheds. After the DEM grid was loaded and the stream networks superimposed, the DEM map grid was processed to remove the non- draining zones. The initial stream network and sub-basin outlets were defined based on drainage area threshold approach. The threshold area defines the minimum drainage area required to form the origin of a stream. The smaller the threshold area, the more detailed the drainage network delineated by the interface but the slower the processing time and the larger memory space is required. In this study, defining of the threshold drainage area was defined by using the threshold value. Besides those sub-basin outlets created by the interface, outlet was also manually added at the Dolalghat gauging station where sensitivity analysis, calibration and validation tasks were later performed. Then watershed delineation activity was finalized by calculating the geomorphic sub-basin parameter.

\subsection{Hydrologic response unit analysis}

Hydrologic response units (HRUs) are lumped land areas within the sub-basin that are comprised of unique land cover, soil, slope and management combinations. HRUs enable the model to reflect differences in evapotranspiration and other hydrologic conditions for different land covers and soils. The land use and the soil data in a projected Grid file format were loaded into the Arc SWAT interface to determine the area and hydrologic parameters of each land-soil category simulated within each subwatershed. A look-up table that identifies the 4-letter SWAT code for the different categories of land cover/land use was prepared to relate the grid values to SWAT. Calculation of the area covered by each land use and reclassification were done. The same techniques as of the land use was applied to soil layer in the map by linking it to the user soil database information by loading the soil look-up table and reclassification applied. The land slope classes were also integrated in defining the hydrologic response units. The DEM data used during the watershed delineation was also used for slope classification. The multiple slope discretization operation was preferred over the single slope discretization as the sub-basins have a wide range of slopes between them. Based on the suggested minimum, maximum, mean and median slope statistics of the watershed, four slope classes $(0-5,5-10,10-30$ and $>30)$ were applied and slope grids reclassified. The HRU distribution in this study was determined by assigning multiple HRU to each sub-watershed. In multiple HRU definition, a threshold level was used to eliminate minor land uses, soils or slope classes in each sub-basin. Land uses, soils or slope classes which cover less than the threshold level was eliminated and the area of the remaining land use, soil, or slope class was reapportioned so that $100 \%$ of the land area in the sub-basin was modeled. The threshold levels set is a function of the project goal and amount of detail required. Use a larger number of sub-basins than larger number of HRUs in a subbasin; a maximum of 10 HRUs in a sub-basin is recommended. Hence, taking the recommendations in to consideration, $5 \%, 5 \%$, and 5\% threshold levels for the land use, soil and slope classes were applied, respectively to encompass most of spatial details.

\subsection{Importing climate data}

The climate of a watershed provides the moisture and energy inputs that control the water balance and determine the relative importance of the different components of the water cycle. The climatic variables required by SWAT daily precipitation, maximum and minimum temperature, solar radiation, wind speed and relative humidity were prepared in the appropriate dbase format. Due to data availability and quality, daily precipitation, and maximum and minimum temperature in dbase format were the climatic input variables imported together with their weather location. And due to lack of complete weather data the Hargreaves method which uses daily maximum and minimum temperature, was used to determine the potential evapotranspiration.

\subsection{Model calibration}

Calibration is the process of gathering the conceptual parameters, and is done as a forerunner to testing of the model hypothesis. During calibration, parameters of unmeasured variables are estimated using information that is available from the real system. The 12 years of observed series of flow at Dolalghat gauging station is divided into three-time frames, namely: the 'warming-up', 'calibration' and 'validation' periods from 1990-94, 1995-1999 and 2000-2006, respectively. The provision of the warming up period is to initialize unknown variables such as moisture content.

Calibration for the water balance was done for average monthly conditions. As the parameters affecting the storm flow and baseflow are not the same, the calibration was done separately for both by considering the resultant hydrograph as the basis for judgment. The storm flow was calibrated by adjusting the sensitive parameters which affect storm flow like CN2 (Initial SCS runoff curve number for moisture condition II), Ch_N (Manning's "n" value for the main channel) and Esco (Soil evaporation compensation factor). Preliminary Calibration of base-flow was performed by judging the flows during the dry months from the hydrograph and adjusting the sensitive parameters which affect groundwater contribution. The most sensitive base-flow parameters which were adjusted were GW_Revap (Groundwater "revap" coefficient), REVAPMN (threshold depth of water in the shallow aquifer for "revap" or percolation to occur), and GWQMN (depth of water in the shallow aquifer required for return flow to occur). The simulated versus observed values for each adjustment were evaluated with coefficient of determination (R2) and Nash-Sutcliffe efficiency. The parameters were adjusted until the R2 and ENS results 
reached a desired value. However, after adjustments of baseflow parameters, the storm flow was checked because the adjustments of the base-flow parameters will affect the storm flow in some way. Once the water balance was calibrated, temporal flow calibration was performed at each step by adjusting parameters which affects the shape of the hydrograph. The parameters adjusted were Ch_K (effective hydraulic conductivity in main channel alluvium), alpha_BF (baseflow alpha factor), Surlag (Storm flow lag coefficient) and GW-Delay (Groundwater delay time). Maximum and minimum parameter value limits were maintained to keep the output values within a reasonable value range. Finally, the calibrated model was re-run to provide the best fit between the measured and simulated data.

\subsection{Model validation}

In order to utilize the calibrated model for estimating effectiveness of future potential management practices, the model was tested against an independent set of measured data. As the model, predictive capability was demonstrated as being reasonable in both the calibration and validation phases, SWAT model can be used for future predictions under different scenarios. In this study, the model was validated with independent validation period of $2000-2006$.

\section{RESULTS AND DISCUSSION}

\subsection{Catchment Characteristics of Indrawati Basin}

The watershed delineation and HRU definition in the Indrawati Basin gave effective watershed area $1130 \mathrm{~km} 2$ which resulted in 21 sub-basins with 555 HRUs. The area coverage by the major land use types in each HRU is presented in table below.

\begin{tabular}{|l|l|l|l|}
\hline land use & SWAT CODE & $\begin{array}{l}\text { Area in } \\
\text { (ha) }\end{array}$ & $\begin{array}{l}\text { \%Watershed } \\
\text { Area }\end{array}$ \\
\hline Forest & FRST & 635398 & 48.28 \\
\hline Shrubs & SHRB & 150297 & 11.42 \\
\hline $\begin{array}{l}\text { Agricultural } \\
\text { land }\end{array}$ & AGRL & 423951 & 32.21 \\
\hline Barren land & BRLD & 58107 & 4.41 \\
\hline Water body & WATB & 10606 & 0.80 \\
\hline Ice & ICES & 37685 & 2.86 \\
\hline
\end{tabular}

Table 3. Land Use Characteristics in the project site
The major portion of the watershed is covered by the Forest area which accounts for $48.28 \%$ of the total watershed area. Agricultural land constitutes the second largest portion of the watershed with $32.21 \%$.

\begin{tabular}{|l|l|l|l|}
\hline Name & Swat & Area (ha) & \% Area \\
\hline $\begin{array}{l}\text { Dystric } \\
\text { Cambisols }\end{array}$ & Bd34-2bc & 728609 & 55.93 \\
\hline Gleysols Luvisols & GL & 72502 & 5.56 \\
\hline Lithosols & I-Bh-U-c & 501494 & 38.49 \\
\hline
\end{tabular}

Table 4. Dominant Soil type

Similarly, the major soil types of Indrawati Basin are presented in Table below. Three major soil types are observed within the basin. The dominant soil type in the watershed is the Dystric Cambisols followed by Lithosols. Table below shows the areas in the basin under different slope classes. From the table, most of the catchment area is observed lies under the slope class 30100. It accounts to a value of $74.6 \%$.

\begin{tabular}{|l|l|l|}
\hline Slope Class & Area in (ha) & \% Watershed Area \\
\hline $0-5$ & 9423 & 0.71 \\
\hline $5-10$ & 19719 & 1.50 \\
\hline $10-30$ & 213082 & 16.2 \\
\hline $30-100$ & 982341 & 74.6 \\
\hline$>100$ & 91797 & 6.97 \\
\hline
\end{tabular}

Table 5. Slope classification

\subsection{Model Calibration}

Manual Calibration was done by changing the sensitive parameter, after the Manual-calibration, best fit parameter values which have effect on the runoff were obtained. The parameter values thus obtained were used for the climate data and future projection of the Indrawati basin.

For best fit parameter values, CN_2 was calibrated to adjust the surface flow, and it was decreased by $40 \%$ because of its higher potential to contribute to storm flow. Another parameter to adjust the same flow component was ESCO, which accounts for the easiness with which water from lower layers is available for evaporation. Lower value accounts for higher evapotranspiration. The value of ESCO was set to 2 for forest areas and was set to 1.5 for agricultural land. As similar way canopy storage was made higher for forested areas and lower for agricultural land. For adjusting subsurface flow, GWQMN water 


\begin{tabular}{|l|l|l|l|l|l|}
\hline \multirow{2}{*}{ Parameters } & \multirow{2}{*}{ Rank } & \multicolumn{2}{|l|}{ Bound } & \multicolumn{2}{l|}{ Calibration Results } \\
\cline { 3 - 6 } & & Lower & Upper & Fitting & Method \\
\hline CN2 & 1 & -25 & 25 & 0.6 & Multiply \\
\hline Sol_Awc & 2 & -25 & 25 & 0.8 & Multiply \\
\hline Sol_K & 3 & -25 & 25 & 0.7 & Multiply \\
\hline GWQMN & 4 & 0 & 5000 & 3500 & Replace \\
\hline Ch_K2 & 5 & 0 & 150 & 110 & Replace \\
\hline CH_N2 & 6 & 0 & 1 & 0.05 & Replace \\
\hline Esco & 7 & 0 & 1 & 2 & Replace \\
\hline Gw_revap & 8 & 0 & 20 & 3.4 & Replace \\
\hline Canmx & 9 & 0 & 10 & 8.5 & Replace \\
\hline Alpha_Bf & 10 & 0 & 1 & 0.1 & Replace \\
\hline Surlag & 10 & 0 & 1 & 14 & Replace \\
\hline
\end{tabular}

Table 6. Model calibration parameter

depth in the shallow aquifer was adjusted. The value of GWQMN was increased to $3500 \mathrm{~mm}$. The default value of 0.014 for Ch_N2 is, of course, unrealistic; hence, it was increased to 0.05 , to account for the overall roughness of the channel bed. Parameter Ch_K2 adjusts the water exchange from ground water to river and was found to be very sensitive to adjust the shape of hydrograph, especially for low flows (dry Season). The value of Ch_K2 was increased to $110 \mathrm{~mm} / \mathrm{hr}$. ALPHA_BF was also used to smoothen the shape of hydrograph, especially for recession period, and it was increased to 0.1. The SURLAG coefficient was replace to 14 . Hence was essential in adjusting the base flow component of the hydrograph. The other sensitive parameters along with their sensitivity ranking and fitting values are provided.

\subsubsection{Calibration Period (1994 - 1999):}

For the calibration period, the simulation of flow with the observed values suggested that the model had a strong predictive capability with $\mathrm{ENS}=0.901$ and $\mathrm{R}^{\wedge} 2=0.951$.

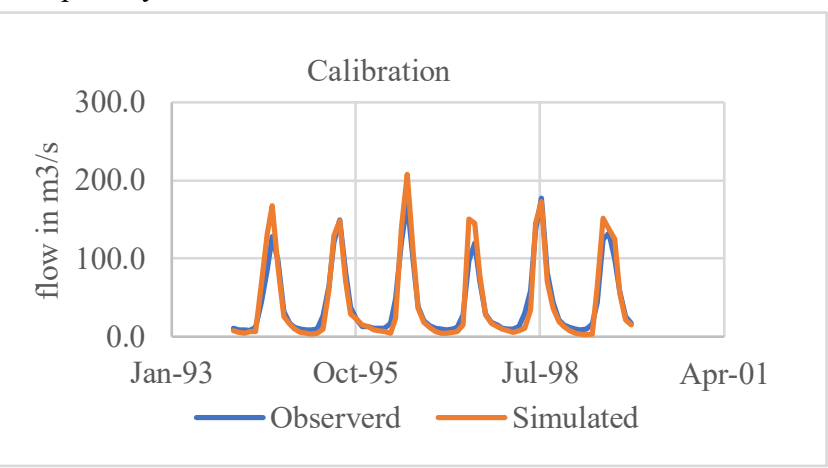

Figure 3. Observed \& Simulated monthly flow hydrographs for calibration period
It can be observed from Figure 3 that the model simulates the flow very well but was not able to catch isolated the high flow events.

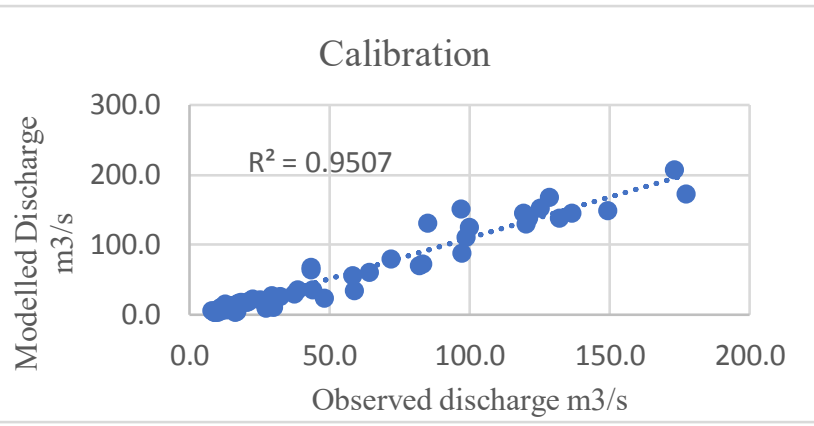

Figure 4. Comparison of Observed and Simulated monthly flow for calibration period

\subsubsection{Validation Period (2001-2006):}

Validation for the model was done for the independent validation data set of six years (2001-2006). The model was again found to have the strong predictive capability with the flow simulation. The ENS value was found to be 0.906 and the $\mathrm{R}^{\wedge} 2$ value as 0.937 . Fig. 5 and 6 show the comparison between simulated and observed mean monthly flows for the validation period.

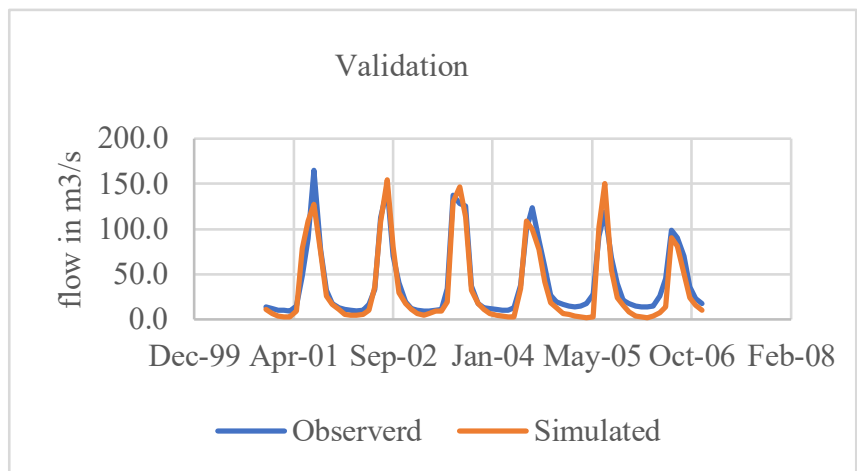

Figure 5. Observed \& Simulated monthly flow hydrograph for validation

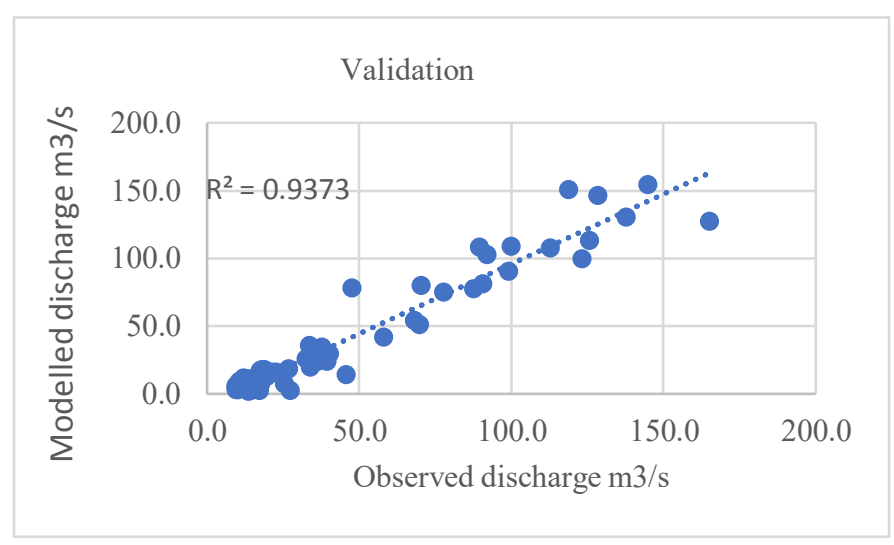

Figure 6. Comparison of Observed and Simulated monthly flow for validation period 


\subsection{Discussions}

In general, there was good agreement between measured and simulated monthly stream flow (NSE $=0.901)$ for the calibration period. The corresponding simulation efficiencies for the validation period were 0.906 respectively. As can be read from the figure, higher precipitation is clearly reflected by the response on water. However, the simulation of dry season flow was slightly underestimated but overall, the agreement between the observed and simulated stream flow was acceptable. The groundwater parameters presented some difficulties in the calibration exercise, as there was not adequate information on their estimates for this region. The peak flows and peak sediment loads were also not adequately simulated, which could be attributed to inadequate representation of the spatial variability of rainfall. However, the statistical and graphical evaluations of the model performance showed that it could be reliably used for simulating hydrology in catchments with readily available observed data. Simulated monthly water yield at Dolalghat is in table below:

\begin{tabular}{|r|r|r|r|r|r|r|r|r|r|r|r|r|r|}
\hline \multicolumn{10}{|c|}{ Simulated Monthly water yield at Dholalghat Station (mm) } \\
\hline & \multicolumn{10}{|c|}{ Month } \\
\cline { 2 - 18 } & Jan & Feb & Mar & Apr & May & Jun & Jul & Aug & Sep & Oct & Nov & Dec & Total \\
\hline 1994 & 7.2 & 5 & 4.7 & 6.2 & 6.7 & 67.9 & 131.5 & 168.1 & 88.4 & 25.7 & 16.3 & 10.3 & 538 \\
\hline 1995 & 6 & 4.3 & 3.8 & 4.7 & 9.8 & 60.2 & 129.3 & 148.6 & 72.1 & 29.5 & 22.2 & 14.9 & 505.4 \\
\hline 1996 & 12.5 & 8.6 & 8.1 & 6.2 & 1 & 23.8 & 138.5 & 207.8 & 110.3 & 35.9 & 18.2 & 11.9 & 582.8 \\
\hline 1997 & 6.6 & 4.8 & 4.5 & 5.4 & 6.9 & 15.2 & 150.6 & 145.1 & 79.6 & 27.8 & 17.3 & 12.8 & 476.6 \\
\hline 1998 & 10 & 7.5 & 5.3 & 7.1 & 10.4 & 34.3 & 144.8 & 173.2 & 70.4 & 36 & 19.3 & 12.9 & 531.2 \\
\hline 1999 & 7.1 & 4.2 & 3.2 & 2.8 & 3.2 & 64.1 & 151.9 & 137.8 & 125.5 & 55.8 & 21.5 & 14.7 & 591.8 \\
\hline 2001 & 6.4 & 4.1 & 3.1 & 3.2 & 9.2 & 78 & 108.4 & 127.1 & 74.8 & 26.1 & 17 & 10.7 & 468.1 \\
\hline 2002 & 5.8 & 4.4 & 4.8 & 5.3 & 10 & 35.8 & 107.7 & 154.5 & 79.9 & 29.6 & 17.9 & 11.5 & 467.2 \\
\hline 2003 & 6.4 & 4.6 & 6.2 & 9 & 9 & 19.4 & 130.2 & 146.5 & 113.3 & 32.1 & 17.6 & 11.3 & 505.6 \\
\hline 2004 & 6.4 & 4.5 & 3.6 & 2.9 & 2.9 & 34.4 & 108.6 & 99.3 & 77.3 & 41.8 & 18.7 & 12.6 & 413 \\
\hline 2005 & 6.9 & 5.3 & 4 & 3.2 & 2.1 & 2.7 & 102.7 & 150.5 & 54 & 24 & 16.1 & 8.2 & 379.7 \\
\hline 2006 & 3.8 & 2.3 & 1.8 & 3.3 & 7.3 & 14.1 & 90.6 & 81.3 & 51.1 & 23.8 & 15.8 & 9.7 & 304.9 \\
\hline Avg & 7.092 & 4.967 & 4.425 & 4.9417 & 6.542 & 37.49 & 124.6 & 144.98 & 83.06 & 32.34 & 18.2 & 11.79 & 480.36 \\
\hline \multicolumn{10}{|c|}{ Table 7.} & Simulated Monthly water yield & & & \\
\hline
\end{tabular}

\subsection{Assessment of future hydrology Comparison of flow in historical and projected flow series}

The calibrated hydrological model was run for the future climate change scenario from 2031-2050 using the RegCM4-LMDZ4 data and the relative changes with the baseline scenarios from $1994-2013$ were analyzed. The time periods were selected to consider a 20-year period for both the historical and future series. The simulated historical data from 1994 - 2013 was considered as the baseline data to improve the homogeneity of the comparison of model simulated historical and projected flows. This also reduces the uncertainty arising from model simulations. The comparison suggests that the historical trend of flow is decreasing at the rate of 0.55 cumecs/year. According to RegCM4-LMDZ4 simulations, the trend is going to continue but at a flatter rate. The decreasing trend is observed to be very less. This also gives an indication of stable or increasing flows after the 2050s. However suggest a drop in annual flows to 32.3 cumecs in the future as compared to the 38.2 cumecs in historical

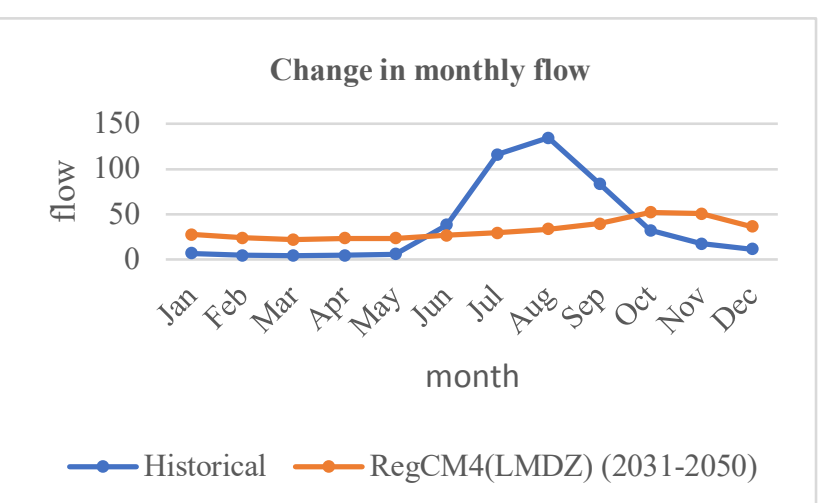

Figure 7. Flow comparison between historical and future

scenarios.

\subsection{Change in monthly flow}

The characteristic peak flow month in the historical scenario is August but the RegCM4-LMDZ4 led simulated flows suggest a shift in monthly peak to October suggesting decrease in monsoon flows and a subsequent significant increase in flows from October to January. It can be incurred that from the water availability point of view, climate change is not going to impact greatly the basin water resources. However, monthly variations in flow are quite high and a significant decrease in monsoon flows can have a major impact on the operation of many water resources project in the region.

\section{$5.6 \%$ Change in flow relative to historical monthly average}

Possible water withdrawals from the river under no storage condition or the storage reservoir capacity and/or operation of the reservoir depend on the monthly availability of the flow and its variation. To evaluate this aspect of flow, the percentage change in the average of monthly flows for the projected periods versus the baseline average monthly values were calculated and are depicted in figure 8.

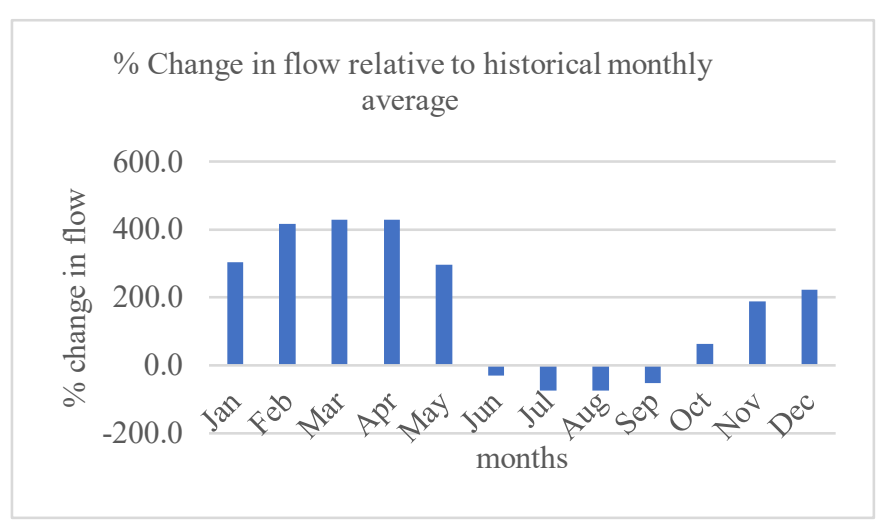

Figure $8 . \%$ change in flow relative to historical monthly data 
The changes in monthly flows vary from decrement up to $75 \%$ in August to increments by more than $303 \%$ relative to historical monthly average in January. Most of the flow is increasing during the lean period and decreasing in June, July, August, and September. Changes in the operation rules moreover become a necessity to deal with these changes in monthly flows ultimately.

\section{CONCLUSIONS}

The watershed simulation model robust hydrological model Soil and Water Assessment Tool (SWAT) was applied to Indrawati Basin at Dolalghat to simulate the discharge at the outlet. Likewise, The RegCM4-LMDZ4 projected data was used in the SWAT model to assess the possible climatic impacts on the hydrology of the Indrawati River Basin. Given the complexities of a watershed and the large number of interactive processes taking place simultaneously and consecutively at different times and places within a watershed, it is quite remarkable that the simulated results comply with the measurements to the degree. There was good agreement between measured and simulated monthly stream flow $(\mathrm{NSE}=0.901)$ for the calibration period. The corresponding simulation efficiencies for the validation period was 0.906 . The fair matching of the hydrographs and the graphs following the trend of precipitation shows a good predictive capability of the model.

The comparison of model simulated historical and projected flows suggests that the historical trend of flow is decreasing at the rate of 0.55 cumecs/year. According to RegCM4-LMDZ4 simulations, the trend is going to continue but at a flatter rate. The decreasing trend is observed to be very less. The results with the GCM led simulations in this study have shown a peculiar result. The results suggest a drop-in monsoon flows and increase in dry season flows thereby suggesting a shift in peak flows from August to October. This is an atypical result as compared to the ongoing research in the river basins in Nepal. This can arise due to the inability of the GCM to project the future as per the hydrological conditions in the area. It has been well documented that the GCM led projections can have a very high degree of uncertainty associated with them.

\section{REFERENCES}

Agarwal, A. B. 2014. Analysis of future precipitation in the Koshi River Basin, Nepal. J. Hydrol. 513, 422-434.

Agrawala, S. R. 2003. Development and Climate Change in Nepal: Focus on Water Resources and Hydropower. paris,France: Organization for Economic Cooperation and Development.

Arnold, J. G. 1998. Large Area Hydrologic Modeling and Assessment - Part 1: Model development. Journal of the American Water Resources Association 34, 73-89.

Babel, M. B. 2014. Climate change and water resources in the Bagmati River Basin, Nepal. Theor. Appl. Climatol. 115, 639654.
Bhattarai, M. D. 2002. Integrated Development and Management of Water Resources for Productive and Equitable Use in the Indrawati River Basin, Nepal. Kathmandu.

Church, J. A. 2006. A 20th century acceleration in global sea level rise. Retrieved 08 04, 2017, from ipcc: https://www.ipcc.ch/pdf/assessmentreport/ar5/syr/AR5_SYR_FINAL_SPM.pdf

Crawford, N. H. 1966. Digital Simulation in hydrology:Stanford Watershed Model IV. Palo Alto, Calif., Tech. Rep. No. 39: Stanford Univ.

Devkota and Gyawali. 2015. Impacts of climate change on hydrological regime and waterresources management of the Koshi River Basin, Nepal. Journal of Hydrology: Regional, 502515.

DHM. 2016. hydrological-station. Retrieved 12 16, 2016, from http://www.dhm.gov.np/hydrological-station/

Dufresne, J. L. 2013. Climate change projections using the IPSLCM5 Earth System Model: from CMIP3 to CMIP5. Clim Dyn (2013) 40, 2123-2165. DOI 10.1007/s00382-012-1636-1.

FAO. 2002. FAO/UNESCO Digital Soil Map of the World and Derived Soil Properties. FAO, Rome.: Land and Water Digital Media Series \#1 rev 1. .

Gassman P.W., R. M. 2007. The Soil and Water Assessment Tool. In Historical Development, Applications, and Future Research Directions. Transactions of the ASABE Vol. 50(4): (pp. 1211-1250).

Giorgi, F. a. 2012. RegCM4: model description and preliminary tests over multiple CORDEX domains . Clim Res, 52:7-29.

Gurung, G. B. 2009. Integrated approach to climate change adaptation. J. For. Livelihood, 90-98.

ISET(N). 2009. Vulnerability through the Eyes of Vulnerable: Climate Change Induced Uncertainties and Nepal's Development Predicaments. kathmandu,Nepal: Institute of for Social and Environmental Transition - Nepal (ISET-N).

Levitus, e. a. 2009. Global ocean heat content 1955-2008 in light of recently revealed instrumentation problems. Geophys, 36 .

Madhav Karki, P. M. 2008. Climate Change and its Increasing Impacts in Nepal. Retrieved 07 10, 2017, from http://www.nepjol.info/index.php/INIT/article/view/2425

Russell., R. 2017, 08 04. Climate Modeling. Retrieved from windows to universe: https://windows2universe.org/?page=/earth/climate/climate_mo deling.html\&back=/search/search_navigation.html\&edu=mid

Santer, B. 1996. A search for human influences on the thermal structure of the atmosphere. In Nature vol 382 (pp. 39-46). 
Sharma, C. 2002. Effect of Melamchi Water Supply Project on Soil and Water Conservation in the Indrawati River Basin, Nepal. In ISCO Conference.

Sharma, R. S. 2005. Hydrological change and its impact on water resources of Bagmati Watershed, Nepal. J. Hydrol. 327, 315322.

Team-Nepal, C. S. 1997. Climate Change Vulnerability and Adaptation: Nepal Water Resources. Washington, DC: prepared as part of the US Country Studies Program.

Trenberth, K. 2011. Changes in precipitation with climate change. Clim. Res. 47, 123-138.

Vijaya, V. I. 2011. A review of climate change, mitigation and adaptation. Renew. Sustain. Energy Rev., 878-897.

Winchell, M. S. 2008. ArcSWAT 2.0 Interface for SWAT 2005,User Manual. 720 East Blackland Road- Temple, TEXAS 76502 .
Shrestha et al,. 2015. Modelling the potential impacts of climate change on hydrology. Environ Earth Sci.

Survey Department. 1996. Retrieved 12 2016, from http://dos.gov.np/language/en/

SWAT. (2009). Retrieved 11 30, 2016, from Swat documentation: http://www.brc.tamus.edu/swat/swatmod.html

Xu YP, Z. X. 2013. Impact of climate change on. Hydrology, $51-60$.

Xu, C.-y. 2002. HYDROLOGIC MODELS. Uppsala University Department of Earth Sciences Hydrology. 